\title{
ACOX2 Gene
}

National Cancer Institute

\section{Source}

National Cancer Institute. ACOX2 Gene. NCI Thesaurus. Code C96441.

This gene is involved in fatty acid metabolism. 